\title{
Assessing the origin of Neotropical mountain dung beetle assemblages (Scarabaeidae: Scarabaeinae): the comparative influence of vertical and horizontal colonization
}

\author{
- $\quad$ Federico Escobar ${ }^{1,2,3}$, \\ - Jorge M. Lobo ${ }^{4}$ and \\ - Gonzalo Halffter ${ }^{1}$
}

${ }^{1}$ Departamento de Ecología y Comportamiento Animal, Instituto de Ecología, AC, Xalapa, Veracruz, México,

${ }^{2}$ Programa de Inventarios de Biodiversidad, Instituto Humboldt, Santafé de Bogotá, Colombia,

${ }^{3}$ Department of Zoology and Entomology, University of Pretoria, 0002 Dierkunde Building, Pretoria, South Africa and

${ }^{4}$ Departamento de Biodiversidad y Biología Evolutiva, Museo Nacional de Ciencias Naturales (CSIC), Madrid, Spain

[Figures and tables at the bottom of the document]

\section{Abstract}

Aims The fauna of mountains and their surrounding regions are likely to be influenced principally by two biological processes: horizontal colonization along similar altitudinal levels by elements originating from lineages inhabiting higher latitudes; and vertical colonization by lineages from the same latitude, but at lower altitudes. We examine whether the expected patterns derived from the latter process can be observed in mountain dung beetle assemblages. Specifically, we study the variation in species composition and richness with altitude in five regions spanning elevation gradients, analysing whether the altitudinal rates of change in the number of species and genera differ, and whether beta-diversity scores for adjacent sites in each altitudinal gradient are different for species and genera.

\section{Location Eastern Cordillera of the Colombian Andes.}

Methods Field work was carried out in 1997-99 at 27 sites in five regions with elevation gradients, with 10-32 pitfall traps placed in each site. For each altitudinal level the 
numbers of species and genera were analysed with respect to altitude, and the slope of the linear regression between these variables was calculated. The slope of the curve of the altitude against the cumulative number of species and genera was also calculated for each altitudinal gradient to describe the compositional change between adjacent sites (beta diversity). Species and generic slopes were compared using analysis of covariance. The turnover of species along each altitudinal gradient was measured using presence/absence data and Cody's beta-diversity index between adjacent pairs of sites. A cluster analysis was used to detect faunistically homogeneous groups of localities.

Results Species richness always decreased with altitude, although the slopes did not differ significantly from zero. The number of genera also decreased with increasing altitude, but generally at a significantly slower rate than for species. Variation in the species beta-diversity scores between altitudinal levels did not follow a homogeneous pattern in the different regions. Two main altitudinal groups of sites with a boundary $c$. $1500-1750 \mathrm{~m}$ a.s.l. can be detected with respect to faunistic similarity. Low- and midaltitude sites are inhabited by all of the genera (19) and $80 \%$ of all species collected. Eight genera and 61 species (c. $60 \%$ of the total) are unable to inhabit high-altitude sites, and only 20 species appear to be exclusive to these high-altitude environments ( $>2000 \mathrm{~m}$ a.s.1.).

Main conclusions The dominant processes explaining dung beetle composition in the high north-eastern Andean mountains are probably those of vertical colonization. The limited role of horizontal colonization processes, or colonization from northern or southern lineages, could be a consequence of the isolation and recent geological origin of these mountains.

\section{Introduction}

It has long been recognized that some of the biota that currently occur in temperate and tropical mountains are physiognomically similar to groups that inhabit higher latitudes, and that changes in the assemblages with altitude are equivalent to latitudinal changes (von Humboldt, 1805; Merriam, 1894; Flenley, 1979; Stevens, 1992). Biogeographers have now established that behind this general pattern of similarity lies an evolutionary process tied to the recent climatic cycles of the Pleistocene and the associated disruption of the assemblages that co-evolved and persisted for millions of years (Brown \& Lomolino, 1998; Hewitt, 2000). Owing to this process, the mountainous biota of some low-latitude regions may be phylogenetically related to that inhabiting high-latitude 
biomes (Vuilleumier \& Simberloff, 1980; Brown, 1995). However, when low-latitude mountain areas are disconnected or isolated from the temperate regions to the north and the south of them, the possibility of dispersal by lineages from these regions may be impeded, resulting in a tropical mountain biota with a low species richness that is phylogenetically related to the biota of surrounding lowlands (Janzen, 1967; Brown \& Lomolino, 1998; Channell \& Lomolino, 2000).

Taking these ideas into account, studies of the altitudinal variation in dung beetle species richness and community composition around the world have proposed two non-mutually exclusive processes to explain the origins of mountain fauna, the patterns of species richness and variation in composition across altitude: horizontal colonization by elements originating from lineages inhabiting higher latitudes; and vertical colonization by lineages inhabiting the same latitude but at lower altitudes (Lobo \& Halffter, 2000 and references therein). These processes represent the two primary reactions that species can have to changes in environmental conditions: spatial adaptation, which involves shifts in their distribution (Hengeveld, 1997); or morpho-ecological adaptation, involving local adaptation to new conditions (Moritz et al., 2000). The effects of these processes are comparable with the biogeographical consequences of phylogenetic niche conservatism and niche evolution concepts (Wiens \& Donoghue, 2004), and can help explain the two main types of endemism: allochthonous endemism (the reduction of a formerly larger range); and autochthonous endemism (local speciation).

These processes would be expected to differ not only in their consequences, but also in the spatial and temporal scales on which they operate. Horizontal colonization assumes the geographical displacement of taxa or of their ancestors in relatively recent geological times, and would generate both a clear pattern of altitudinal substitution between higherlevel taxa with different evolutionary histories, and an attenuated gradient of reduction in species richness with altitude, because the decrease of species richness with altitude is attenuated by the incorporation of species from distant regions. In contrast, vertical colonization suggests a lower degree of regional dispersal of taxa but a higher relevance of long term speciation processes. In this case, the elevational substitution pattern detected would be lower, but the decrease in species richness would be greater.

As in some European mountain regions (Martín-Piera et al., 1992; Jay-Robert et al., 1997), the Mexican Transition Zone exemplifies horizontal colonization processes, as high-altitude communities are dominated by mountainous Palaeo-American and Nearctic species belonging to genera with diversification centres in the Holarctic region, whereas lowland assemblages are dominated by Neotropical elements (Halffter, 1976; Halffter et al., 1995; Lobo \& Halffter, 2000). The horizontal colonization pattern would then be 
due to the southward shift of northern lineages that have taken place in response to climate changes (Halffter, 1976; Elias, 1994), facilitated by the north-south orientation of North American mountain ranges (Halffter, 1976; Lobo \& Halffter, 2000; Escobar et al., 2005), whereas only a minor role is played by speciation and adaptive evolutionary changes resulting from the isolation and evolutionary divergence after these colonization events (Cruzan \& Templeton, 2000; Hewitt, 2000). In contrast, vertical colonization dominates the expected pattern of species richness and variation in composition observed in some island dung beetle assemblages of south-eastern Asia (Hanski, 1983; Hanski \& Niemelä, 1990; Hanski \& Krikken, 1991).

There is no empirical evidence about the role of vertical colonization and its hypothesized effects on species richness and compositional patterns in continental areas. Evidently, the relative importance of both processes depends on the orientation and location of the mountains, and on their degree of isolation and biogeographical history, as these characteristics greatly influence the refuge and 'corridor' capacity of mountain areas (Rickart, 2001). In this study, we examine five Neotropical altitudinal gradients between 1000 and $2250 \mathrm{~m}$ a.s.1. in the Eastern Cordillera of the Colombian Andes, and determine whether patterns supposedly derived from vertical colonization can be observed, as they are relatively isolated both from northern and southern ranges. Assuming that when the mountain fauna is derived primarily from vertical colonization processes, the compositional and richness variation with altitude should be a consequence of the turnover of species belonging to the same phylogenetic lineages, we examine specifically whether the altitudinal rates of change in the numbers of species and genera are different, and whether beta diversity for adjacent sites on each altitudinal gradient differs for species or genera.

\section{Methods}

\section{Study area and sampling design}

A detailed description of the area and sampling procedures is presented by Escobar et al. (2005). Briefly, the study was carried out on the eastern slope of the Eastern Cordillera in the Colombian Andes (between $00^{\circ} 28^{\prime} \mathrm{N}, 7^{\circ} 17^{\prime} \mathrm{W}$ and $00^{\circ} 23^{\prime} \mathrm{N}, 72^{\circ} 23^{\prime} \mathrm{W}$; Fig. 1), a south-to-north mountain range that separates the territory into large lowland regions (the Amazonian and Orinoquian regions to the east and the Chocó region to the west). Field work was carried out between February 1997 and November 1999 in five areas (Fig. 1). After dividing each area into six 250-m-interval transects, between 1000 and $2500 \mathrm{~m}$ 
a.s.1., 27 sites were sampled with 330 traps. At each site, 10-32 pitfall traps (12.2 \pm 4.8 ; mean $\pm \mathrm{SD}$; traps $1000 \mathrm{~mL}$ capacity, $13 \mathrm{~cm}$ deep, $11 \mathrm{~cm}$ diameter) were placed in the forest $25 \mathrm{~m}$ apart and baited with $50 \mathrm{~mL}$ of human dung. Each trap was left in the field for $48 \mathrm{~h}$. A total of 7894 specimens belonging to 101 species were captured. An evaluation of data completeness using accumulation curves showed that a detectable asymptote was reached in many sites (Escobar et al., 2005), and that in 21 sites (78\%) $>80 \%$ of species appeared to be collected, although in the remaining six sites the mean value of the estimates was $76 \%$. The nonparametric richness estimates indicated that between $75 \%$ and $86 \%$ of the expected maximum number of species for the entire territory were collected (Escobar et al., 2005).

\section{Data analysis}

For each sampling area, the elevational change in number of species and the number of genera were analysed. Curves for the cumulative numbers of observed species and genera against altitude were calculated for each area to describe the compositional change between adjacent sites (beta diversity). The slope of the linear regression of the altitude of sites against the cumulative number of species or genera was calculated for each area. These slopes were compared using analysis of covariance (ANCOVA) to test whether the effect of taxonomic category (species or genus) was statistically significant.

The turnover of species along the altitudinal gradient in each area was measured using presence/absence data and by calculating Cody's beta-diversity index (Cody, 1993)

between adjacent pairs of sites $\left(\beta_{\mathrm{co}}\right)$ as: $\beta_{\mathrm{co}}=1-\left[\frac{a(2 a+b+c)}{2(a+b)(a+c)}\right]_{\text {where } a \text { is the total }}$ number of species or genera that occur in any pair of adjacent sites along a transect, and $b$ and $c$ are the number of exclusive species or genera (those that occur in each site but not in the adjacent one). This index was selected from the large number of beta-diversity measures available because it is one of eight measures recently recommended (Koleff et al., 2003) for its capacity to focus on compositional differences rather than on species richness, and for the higher scores it gives when the proportion of shared species is low and the percentages of species lost and gained are similar. As beta-diversity indices do not reveal whether the values are produced by a gain or loss in the number of species, we also calculated the number of species or genera gained and lost between neighbouring sites. A triangular $Q$-mode similarity matrix of sites was computed from the rectangular matrix of species abundance on each site using the percentage dissimilarity measure (PD; Ludwig \& Reynolds, 1988). To define groups of sites with similar composition, cluster analysis was carried out using the Ward method as clustering strategy, as it allows detection of clusters that are relatively homogeneous with respect to all the variables (Legendre \& Legendre, 1998). Significant clusters were estimated by randomly assigning 
the cases ( 500 random trials) to a given initial partition by a $k$-means procedure, to improve the Euclidean sum of squares (ESS), selecting the solution with the lowest ESS (Wishart, 2000; http://www.clustan.com).

\section{Results}

Species richness of dung beetles decreased with altitude in all five areas, at a rate varying between 3.4 and 13.6 species per $1000 \mathrm{~m}$ altitude, but with a general increase in the number of species at intermediate elevations (Fig. 2). The estimated number of species using three different nonparametric richness estimators (the incidence-based coverage estimator, Chaol and first-order jackknife; Colwell \& Coddington, 1994), follow the same tendency as that of observed richness (Fig. 2; cf. Escobar et al., 2005). The number of genera also decreased with increasing altitude (slopes from -2.57 to -6.0 genera per $1000 \mathrm{~m}$ ). The rate of decrease in the number of genera was generally lower, without an increase at intermediate altitudes (Fig. 2), suggesting that the intermediate peak in species richness is probably the result of an increase in species of the same genera that inhabit adjacent altitudes.

The slopes of the cumulative number of species varied from 8.6 to 22.0 species per $1000 \mathrm{~m}$, with the lowest slope occurring in the northernmost elevational gradient; slopes for the number of genera were significantly lower, varying from 1.6 to 3.6 genera per $1000 \mathrm{~m}$ (Table 1; Fig. 2). Thus the addition of new species with increasing altitude is much higher than the accumulation rate of genera, suggesting that species that appear with increasing altitude generally belong to the same genera that inhabited lower altitudinal levels.

Variations in species beta diversity $\left(\beta_{\mathrm{co}}\right)$ between altitudinal levels do not follow a homogeneous pattern in the different regions (Fig. 3), although there is a general increase in beta diversity between sites at the two highest altitudes. However, these higher $\beta_{\mathrm{co}}$ scores are mainly due to the loss of species, except in the case of the northern altitudinal gradient (site E), where the lack of data for the sites at 1500 and $1750 \mathrm{~m}$ a.s.l. produces an apparent increase in species turnover rates. The beta-diversity scores for generic replacement (mean \pm SE: $0.23 \pm 0.04$ ) are significantly lower than for species $(0.49 \pm 0.05$; Wilcoxon matched pairs, $Z=3.26, P=0.001)$, but show the same general pattern as that observed for species (Fig. 4), so the higher beta scores are mainly due to the loss of genera between altitudinal levels. 
As occurs when a presence/absence matrix is used (Escobar et al., 2005), two main altitudinal groups of sites with a boundary around 1500-1750 $\mathrm{m}$ a.s.l. can be identified according to their faunistic similarity (Fig. 5). Mid-altitude sites harbour all the genera collected (19) and 80\% of total species. Eight genera and 61 species (around $60 \%$ of total) did not inhabit high-altitude sites, and only 20 species appear to be exclusive to these high-altitude environments (Table 2). These belong to the genera Bdelyrus (one species), Canthidium (three species), Canthon (one), Cryptocanthon (two), Deltochilum (five), Dichotomius (one), Ontherus (one), Scybalocanthon (one) and Uroxys (five). Examining the distribution of the two genera with more exclusive species in the group of high-altitude sites, closely related species appear to be segregated both with respect to altitude and between the different mountain regions (Fig. 6).

\section{Discussion}

The decline in species richness with altitude is common, but altitudinal patterns for different groups vary (Rahbek, 1995; Patterson et al., 1998). Elevational patterns in diversity have been related to many contemporary environmental variables (Huston, 1994), but the underlying causal mechanisms behind these correlations remain elusive. It is likely that current patterns are greatly influenced by past environmental changes, and present-day environmental conditions only allow their maintenance (Brown, 2001; Davis \& Shaw, 2001). That is why, rather than identifying the environmental variables correlated with the species richness and variations in faunistic composition, we have sought to explain how mountain species have been able to inhabit these environmentally favourable regions. In our study the results of the accumulation curves, the variation in beta-diversity scores, and the faunistic similarity between sites all suggest that the dominant processes able to explain the observed altitudinal patterns of dung beetle assemblages in the eastern Andean mountains are those of the vertical colonization model. However, it should be taken into account that the present study comprises only a portion of the altitudinal gradient (between 1000 and $2500 \mathrm{~m}$ ), which suggests that caution is needed in proposing generalizations.

As for dung beetles of other tropical regions with high and isolated mountains (Davis et al., 1999), the distinction between low- and high-elevation fauna is well established in the Andes, as is the distinction between lower- and upper-montane fauna (Patterson et al., 1998; Kessler et al., 2001). Although few species are added as altitude increases, and most of the turnover at high-altitude sites is due to the occurrence of a small number of species belonging to the same genera collected at lower altitudes, there are some 
examples indicative of possible in situ speciation, probably resulting from the local adaptation of populations coming from the lowlands. The current spatial segregation among presumed sister species, both between altitudes and between the different mountain regions (genera: Deltochilum, Uroxys and Cryptocanthon), suggests that the complex geological and climatic history of the north Andean mountains could also have favoured the isolation and speciation of populations. Additional phylogeographical studies are needed to delimit the relevance of speciation processes across elevational gradients, and also across the different mountain chains. The strong environmental gradient that a mountain represents can result in adaptive divergence and speciation (gradient model of speciation; Moritz et al., 2000), while the occurrence of related species in different mountain regions is better explained by a traditional vicariance model of speciation.

Recent evidence suggests that climatic oscillations during the Plio-Pleistocene played a minor role in generating vertebrate species in the lowland tropics, perhaps because species responded mainly by migration rather than by adaptive differentiation (Moritz et al., 2000). However, these climatic changes are frequently mentioned as a main source of speciation when the aim is to explain the current distribution of Andean biota (frogs: Duellman, 1979; plants: Gentry, 1982; butterflies: Descimon, 1986; birds: Vuilleumier, 1986). Thus species found at high elevations in tropical America would be recent and geographically limited, possibly indicating the existence of an association between modern diversification processes and recent geological activity (Hewitt, 2001). At least for some vertebrate groups, molecular studies indicate that the tropical Andes contain a higher proportion of young species (Fjeldså, 1994; da Silva \& Patton, 1998), probably owing to the environmental heterogeneity that emerged after the uplift of the Andes beginning in the Miocene (18 Ma), and the speciation processes that occurred during the Plio-Pleistocene glacial periods (García-Moreno et al., 1999; García-Paris et al., 2000). The rapid shifts in the climate and associated changes in the composition and distribution of vegetation during the last two glacial cycles would have generated sufficient opportunity for speciation (Moritz et al., 2000 and references therein).

A clear example of the role of elevation and isolation in the Andean mountains is provided by Cryptocanthon, a genus for which one species occurs in each mountain region. According to Cook (2002), there are 35 species of Cryptocanthon, 23 of which have a narrow geographical distribution occurring at elevations above $1000 \mathrm{~m}$ a.s.l. (Cook, 2002). This high level of endemism is closely related to the loss of the ability to fly. Flightlessness is unusual among dung beetles, because most species need fly to reach ephemeral food resources such as fresh dung (Halffter \& Matthews, 1966). The tendency towards a reduction of metathoracic wings in mountain habitats is a pattern that occurs 
repeatedly in other Coleoptera (Carabidae; Darlington, 1943). These features are suggestive of old taxa that are phylogenetically isolated within their respective lineages, and could indicate a close adaptation to the environment and a relatively long residence time (Ball \& Shpeley, 2000). So beetles with a tendency towards flightlessness, such as Cryptocanthon, have been profoundly affected by the repeated climatic disruptions of the Plio-Pleistocene (Cook, 2002).

Our results show that these Neotropical high-altitude dung beetle assemblages are poor in species, but are singular and distinctive. As found in other tropical studies (Lobo \& Halffter, 2000), the environmental changes associated with increasing altitude generate a notable decrease in species richness and also a slight turnover in the composition of assemblages, mainly due to the loss of species. This probably occurs because Scarabaeinae dung beetles are a monophyletic group (Scholtz, 1990) mostly comprised of warm-adapted species, for which the vertical colonization of these high-mountain environments by lineages distributed at lower altitudes would have been very difficult (Lobo \& Halffter, 2000). Other restrictions to colonizing mountain environments include the general shape of mountains, where area decreases and isolation increases with increasing elevation, resulting in high extinction rates and low colonization rates. Both factors would contribute to a decrease in diversity with altitude (Brown, 2001). Although our collecting efforts did not include sampling above $2250 \mathrm{~m}$ a.s.1., studies carried out on different mountains in the Colombian Andes (Amat-García et al., 1997; Medina et al., 2002) confirm the predominant role of vertical colonization, dominated by species belonging to widely distributed genera with a long evolutionary history in lowlands: species such as Dichotomius, Ontherus and Uroxys.

In contrast to findings for the Mexican Transition Zone (Halffter, 1987; Lobo \& Halffter, 2000), where the north-south orientation of the mountain ranges facilitates the arrival of northern elements, in the northern Andes a lack of horizontal colonization could be a result of the isolation and recent origin of these mountains relative to more northern and southern mountain chains. We suggest that these mountains are being colonized, without much success, by the surrounding Neotropical fauna. However, the presence of the genus Onthophagus in South America could have resulted from the horizontal colonization of elements that have recently penetrated the lowlands, such as species of the clypeatus group. American Onthophagus lineages probably derive from Oriental or Palaearctic taxa, although African lineages appear to be basal in the phylogeny of the genus (Emlen et al., 2005). Currently the distribution of this genus is restricted mostly to forest below $2000 \mathrm{~m}$ a.s.l. (Zunino \& Halffter, 1997), with only a few species successfully colonizing the high Andean mountains. 
The concepts of vertical and horizontal colonization allow us to explain the altitudinal turnover in fauna and, to a lesser extent, the changes in species richness along the elevational gradient, but principally aim to elucidate the role played by historical dispersal and speciation in the formation of mountain assemblages. Integrating large spatial and temporal processes to contemporary patterns, vertical and horizontal colonization concepts provide a theoretical tool for understanding the processes behind the dissimilarity of the altitudinal variation in assemblages, as well as the differences in the rate of species richness decrease with altitude. As Pielou (1979) asks: 'Does the differential migration of species in response to change reinforce or obscure the zonation caused by the zoned climates on a rotating sphere warmed by a small, distant sun?' We believe that dispersal expanding the geographical ranges of species can reinforce the observed biotic zonation in some situations when physical connections are likely. In the case of high northern Andean mountain dung beetles, this does not appear to have been possible.

\section{References}

Amat-García, G., Lopera-Toro, A. \& Amezquita-Melo, S.J. (1997) Patrones de distribución de escarabajos coprófagos (Coleóptera: Scarabaeidae) en relictos del bosque altoandino, cordillera Oriental de Colombia. Caldasia, 19, 19-204.

Ball, G.E. \& Shpeley, D. (2000) Carabidae (Coleoptera). Biodiversidad, taxonomía y biogeografía de artrópodos de México (ed. by J. Llorente, E. González and N. Papayero), pp. 364-399. Universidad Autónoma Nacional de México, .

-

Brown, J.H. (1995) Macroecology. University of Chicago Press, .

Brown, J.M. (2001) Mammals on mountainsides: elevational patterns of diversity. Global Ecology and Biogeography, 10, 101-109.

-

Brown, J.H. \& Lomolino, M.V. (1998) Biogeography, 2nd edn. Sinauer Associates, .

Channell, R. \& Lomolino, M.V. (2000) Trajectories toward extinction: dynamics of geographic range collapse. Journal of Biogeography, 27, 169-179.

-

Cody, M.L. (1993) Bird diversity components within and between habitats in Australia. Species diversity in ecological communities (ed. by R.E. Ricklefs and D. Schulter), pp. 147-158. Chicago University Press, . 
Colwell, R.K. \& Coddington, J.A. (1994) Estimating the extent of terrestrial biodiversity through extrapolation. Philosophical Transactions of the Royal Society of London, Series B, Biological Sciences, 345, 101-118.

Cook, J. (2002) A revision of the neotropical genus Cryptocanthon Balthasar (Coleoptera: Scarabaeidae: Scarabaeinae). The Coleopterist Society Monographs, Patricia Vaurie Series 56 (1), Supplement 1-96. .

Cruzan, M.B. \& Templeton, A.R. (2000) Paleoecology and coalescence: phylogeographic analysis of hypotheses from the fossil record. Trends in Ecology and Evolution, 15, 491496.

Darlington, P.J., Jr (1943) Carabidae of mountains and islands: data on the evolution of isolated faunas, and atrophy of wings. Ecological Monographs, 13, 37-61.

Davis, M.B. \& Shaw, R.G. (2001) Range shifts and adaptive responses to Quaternary climate changes. Science, 292, 673-679.

Davis, A.L.V., Scholtz, C.H. \& Chown, S.L. (1999) Species turnover, community boundaries, and biogeographical composition of dung beetle assemblages across an altitudinal gradient in South Africa. Journal of Biogeography, 26, 1039-1055.

Descimon, H. (1986) Origins of lepidopteran faunas in the high tropical Andes. High altitude tropical biogeography (ed. by F. Vuilleumier and M. Monasterio), pp. 500-532. Oxford University Press, .

-

Duellman, W.E. (1979) The Herpetofauna of the Andes; patterns of distribution, origin, differentiation, and present communities. The South American Herpetofauna: its origin, evolution, and dispersal, Monograph 7 (ed. by W.E. Duellman), pp. 371-459. Museum of Natural History, The University of Kansas, .

Elias, S.A. (1994) Quaternary insects and their environments. Smithsonian Institution Press, .

Emlen, D.J., Marangelo, J., Ball, B. \& Cunningham, C.W. (2005) Diversity in the weapons of sexual selection: horn evolution in the beetle genus Onthophagus (Coleoptera: Scarabaeidae). Evolution, 59, 1060-1084.

Escobar, F., Lobo, J.M. \& Halffter, G. (2005) Altitudinal variation of dung beetle (Scarabaeidae: Scarabaeinae) assemblages in the Colombian Andes. Global Ecology and Biogeography, 14, 327-337.

Fjeldså, J. (1994) Geographical patterns for relict and young species of birds in Africa and South America and implications for conservation priorities. Biodiversity and Conservation, 3, 207-226. 
Flenley, J.R. (1979) The Late Quaternary vegetational history of the equatorial mountains. Progress in Physical Geography, 3, 488-509.

García-Moreno, J., Arctander, P. \& Fjeldså, J. (1999) A case of rapid diversification in the Neotropics. Phylogenetic relationships of Cranioleuca spinetails (Aves, Furnariidae). Molecular Phylogenetics and Evolution, 12, 273-281.

-

García-Paris, M., Good, D.A., Parra-Olea, G. \& Wake, D.B. (2000) Biodiversity of Costa Rican salamanders: implications of high levels of genetic differentiation and phylogeographic structure for species formation. Proceedings of the National Academy of Sciences USA, 97, 1640-1647.

Gentry, A.H. (1982) Neotropical floristic diversity: phytogeographical connections between central and South America, Pleistocene climatic fluctuations, or an accident of the Andean orogeny? Annals of the Missouri Botanical Garden, 69, 557-593.

-

Halffter, G. (1976) Distribución de los insectos en la Zona de Transición Mexicana. Relaciones con la entomofauna de Norteamérica. Folia Entomologica Mexicana, 35, 164.

Halffter, G. (1987) Biogeography of montane entomofauna of Mexico and Central America. Annual Review of Entomology, 32, 95-114.

Halffter, G. \& Matthews, E.G. (1966) Natural history of dung beetles of the subfamily Scarabaeinae (Coleoptera: Scarabaeidae). Folia Entomologica Mexicana, 12-14, 1-132.

-

Halffter, G., Favila, M.E. \& Arellano, L. (1995) Spatial distribution of three groups of Coleoptera along and altitudinal transect in the Mexican Transition Zone and its biogeographical implications. Elytron, 9, 151-185.

Hanski, I. (1983) Distributional ecology and abundance of dung beetles and carrion feeding beetles (Scarabaeinae) in tropical rain forest in Sarawak, Borneo. Acta Zoologica Fennica, 167, 1-45.

Hanski, I. \& Krikken, J. (1991) Dung beetles in tropical forest in Southeast Asia. Dung beetle ecology (ed. by I. Hanski and Y. Cambefort), pp. 179-197. Princeton University Press.

Hanski, I. \& Niemelä, J. (1990) Elevational distribution of dung and carrion beetles in northern Sulawesi. Insects and the rain forest of Southeast Asia (Wallacea) (ed. by W.J. Knight and J.D. Holloway), pp. 145-152. Royal Entomological Society, .

Hengeveld, R. (1997) Impact of biogeography on population-biological paradigm shift. Journal of Biogeography, 24, 541-547. 
Hewitt, G. (2000) The genetic legacy of the Quaternary ice ages. Nature, 405, 907-913. -

Hewitt, G.M. (2001) Speciation, hybrid zones and phylogeography - or seeing genes in space and time. Molecular Ecology, 10, 537-549.

von Humboldt, A. (1805) Essai sur la geographie des plantes. Librarie Lebrault Schoel.

-

Huston, M.A. (1994) Biological diversity. The coexistence of species on changing landscapes. Cambridge University Press, .

-

Janzen, D. (1967) Why mountain passes are higher in the tropics. American Naturalist, 112, 225-229.

Jay-Robert, P., Lobo, J.M. \& Lumaret, J.P. (1997) Altitudinal turnover and species richness variation in European montane dung beetle assemblages. Arctic, Antarctic and Alpine Research, 29, 196-205.

Kessler, M., Herzog, S.K., Fjelds, J. \& Bachå, K. (2001) Species richness and endemism of plant and bird along two gradients of elevation, humidity and land use in Bolivian Andes. Diversity and Distributions, 7, 61-77.

-

Koleff, P., Gaston, K. \& Lennon, J.J. (2003) Measuring beta diversity for presenceabsence data. Journal of Animal Ecology, 72, 367-382.

Legendre, P. \& Legendre, L. (1998) Numerical ecology. Elsevier, .

-

Lobo, J.M. \& Halffter, G. (2000) Biogeographical and ecological factors affecting the altitudinal variation of mountainous communities of coprophagous beetles (Coleoptera, Scarabaeoidea): a comparative study. Annals of the Entomological Society of America, 93, 115-126.

-

Ludwig, J.A. \& Reynolds, J.F. (1988) Statistical ecology: a primer on methods. John Wiley and Sons, .

Martín-Piera, F., Veiga, C.M. \& Lobo, J.M. (1992) Ecology and biogeography of dungbeetle communities (Coleoptera, Scarabaeoidea) in an Iberian mountain range. Journal of Biogeography, 19, 677-691.

Medina, C., Escobar, F. \& Catán, G. (2002) Diversity and habitat use of dung beetles in a restored Andean landscape. Biotropica, 34, 181-187.

Merriam, C.H. (1894) Laws of temperature control of the geographic distribution of terrestrial animals and plants. National Geographic, 6, 229-238. 
Moritz, C., Patton, J.L., Schneider, C.J. \& Smith, T.B. (2000) Diversification of rainforest faunas: an integrated molecular approach. Annual Review of Ecology and Systematics, 31, 533-563.

Patterson, B.D., Stotz, D.F., Solari, S., Fitzpatrick, J.W. \& Pacheco, V. (1998) Contrasting patterns of elevational zonation for birds and mammals in the Andes of southeastern Peru. Journal of Biogeography, 25, 593-607.

Pielou, E.C. (1979) Biogeography. John Wiley \& Sons, .

-

Rahbek, C. (1995) The elevational gradient of species richness: a uniform pattern? Ecography, 18, 200-205.

Rickart, E.A. (2001) Elevational diversity gradients, biogeography and the structure on montane mammal communities in the intermountain region of North America. Global Ecology and Biogeography, 10, 77-100.

Scholtz, C.H. (1990) Phylogenetic trends in the Scarabaeoidea (Coleoptera). Journal of Natural History, 24, 1027-1066.

-

da Silva, M.N.F. \& Patton, J.L. (1998) Molecular phylogeography and the evolution and conservation of Amazonian mammals. Molecular Ecology, 7, 475-486.

Stevens, G.C. (1992) The elevational gradient altitudinal range: an extension of Rapoport's latitudinal rule to altitude. American Naturalist, 140, 893-911.

Vuilleumier, F. (1986) Origins of the tropical avifaunas in the high Andes. High altitude tropical biogeography (ed. by F. Vuilleumier and M. Monasterio), pp. 586-622. Oxford University Press, .

-

Vuilleumier, F. \& Simberloff, S. (1980) Ecology versus history as determinants of patchy and insular distributions in high Andean birds. Evolutionary Biology, 12, 235-379.

Wiens, J.J. \& Donoghue, M.J. (2004) Historical biogeography, ecology and species richness. Trends in Ecology and Evolution, 19, 639-644.

Wishart, D. (2000) FOCALPOINT clustering user guide. Clustan Ltd, .

-

Zunino, M. \& Halffter, G. (1997) Sobre Onthophagus Latreille, 1802 americanos

(Coleoptera: Scarabaeidae: Scarabaeinae). Elytron, 11, 157-178. 


\section{Figures and tables}

Figure 1 The Colombian Andes and geographical locations of the five altitudinal regions sampled (white circles) in the Eastern Cordillera of the Colombian Andes (dark grey). A = Putumayo $\left(00^{\circ} 28^{\prime} \mathrm{N}, 77^{\circ} 17^{\prime} \mathrm{W}\right)$; B = Los Picachos (02 $\left.47^{\prime} \mathrm{N}, 74^{\circ} 51^{\prime} \mathrm{W}\right)$; $\mathrm{C}=$ Farallones de Medina $\left(05^{\circ} 35^{\prime} \mathrm{N}, 73^{\circ} 25^{\prime} \mathrm{W}\right) ; \mathrm{D}=$ Alto Río Cusiana $\left(05^{\circ} 23^{\prime} \mathrm{N}\right.$, $\left.72^{\circ} 42^{\prime} \mathrm{W}\right) ; \mathrm{E}=$ Tamá National Park $\left(07^{\circ} 07^{\prime} \mathrm{N}, 72^{\circ} 14^{\prime} \mathrm{W}\right)$. The two main tropical lowland regions are also indicated. Cells represent a $2^{\circ}$ grid in latitude/longitude co-ordinates.

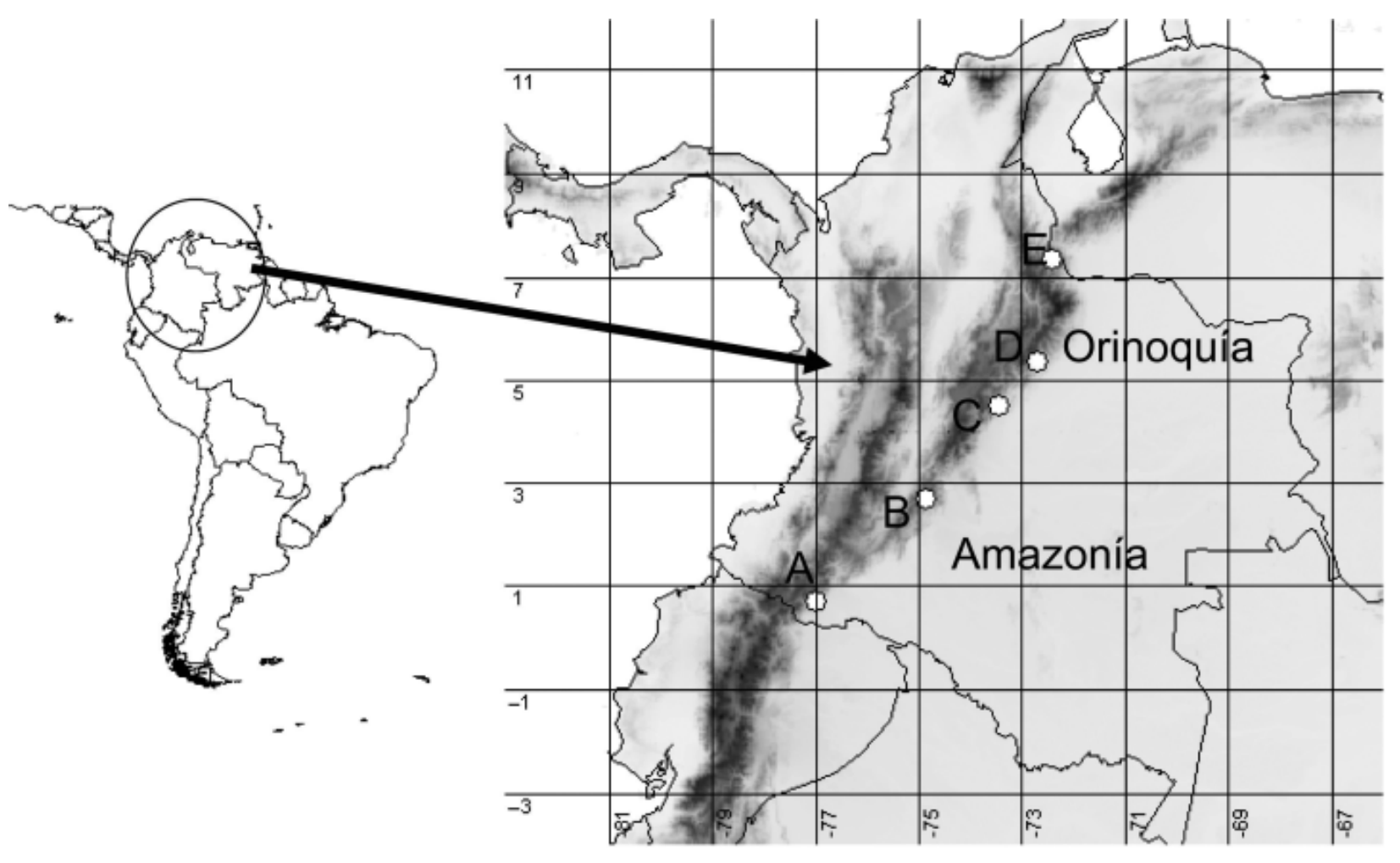


Figure 2 Elevational variation in number of species or genera (solid circles) and cumulative number of species and genera (squares) in each region. Sites as in Fig. 1. Crosses represent mean number of species estimated by three common nonparametric richness estimators that use species-by-sample data (Escobar et al., 2005).
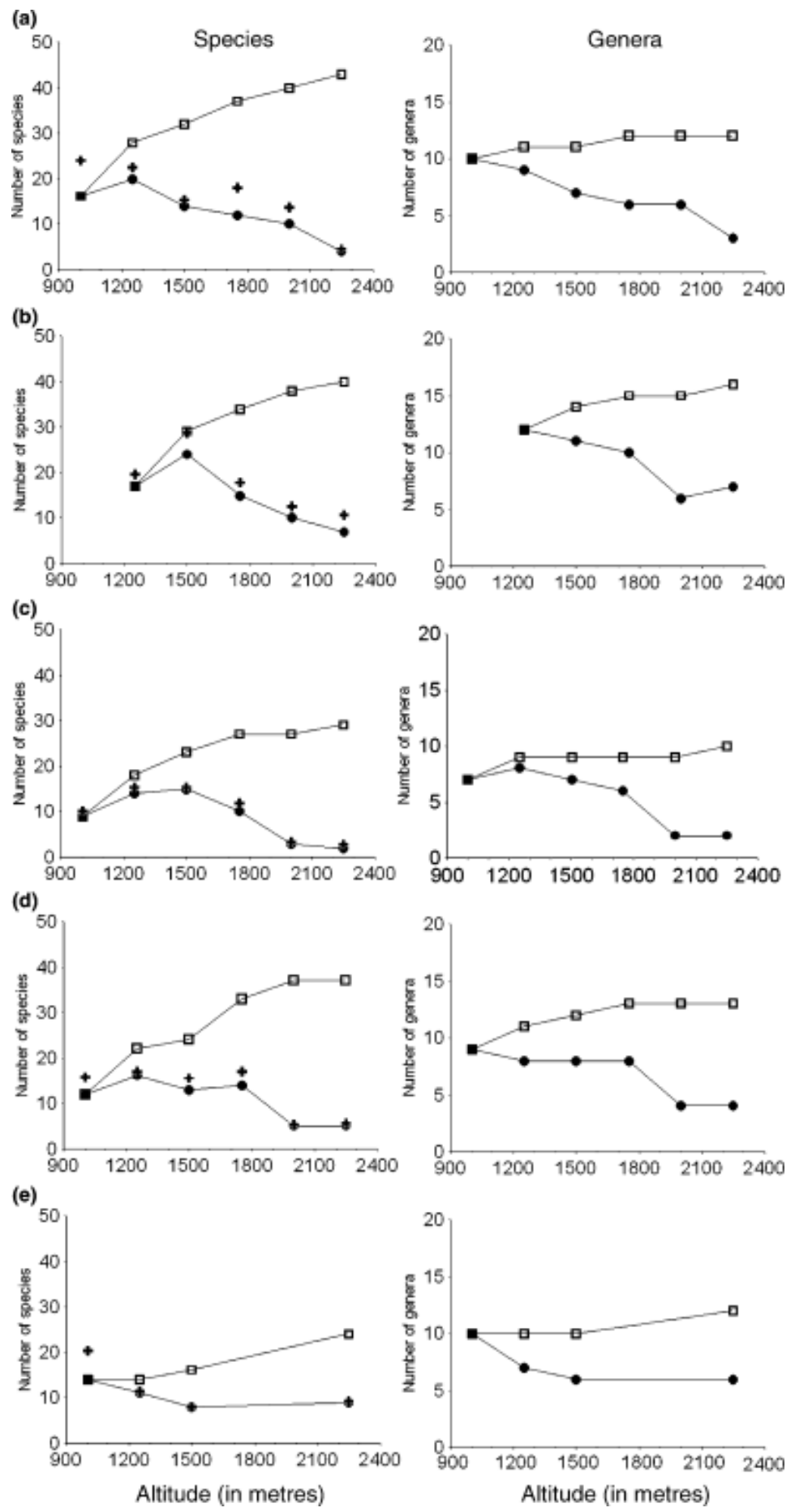
Figure 3 Changes in beta diversity $\left(\beta_{\mathrm{co}}\right)$ for species along each elevational gradient (line). Beta diversity was calculated between two adjacent altitudinal levels. Grey bars, number of species lost; dark bars, number of species gained.
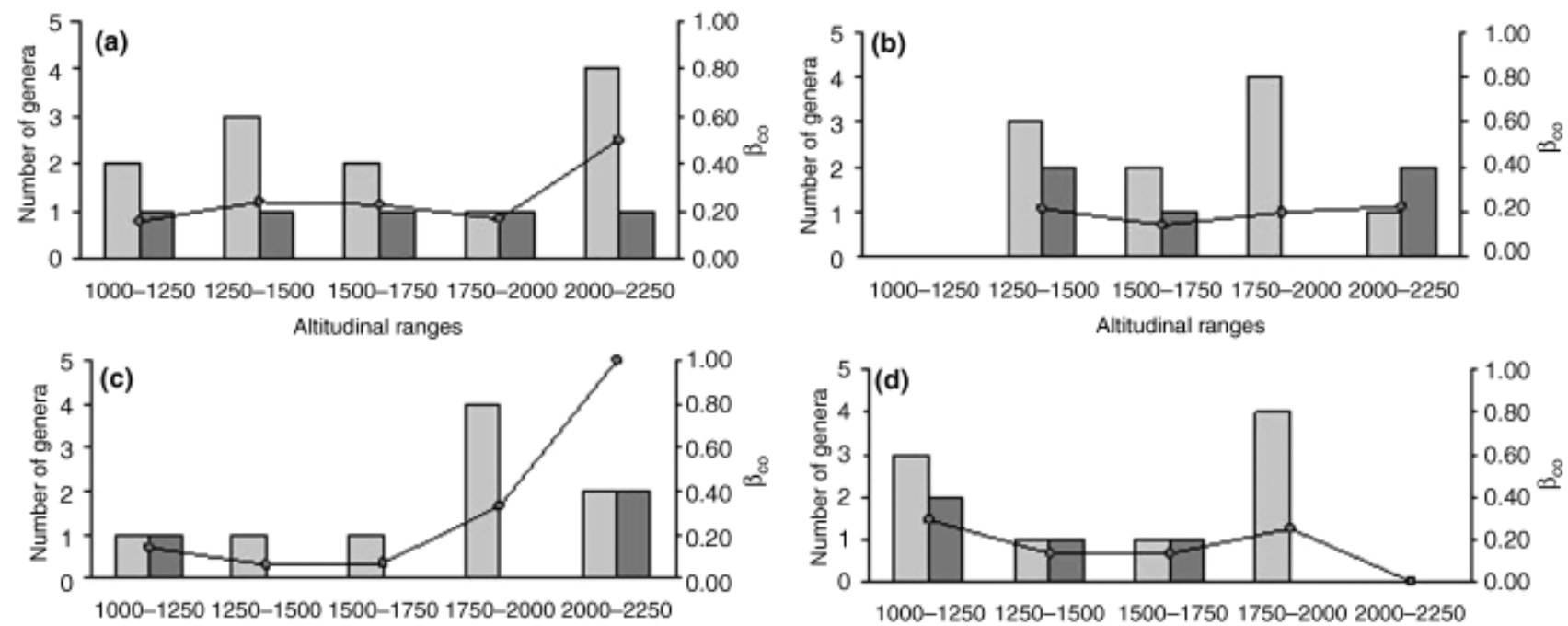

Altitudinal ranges
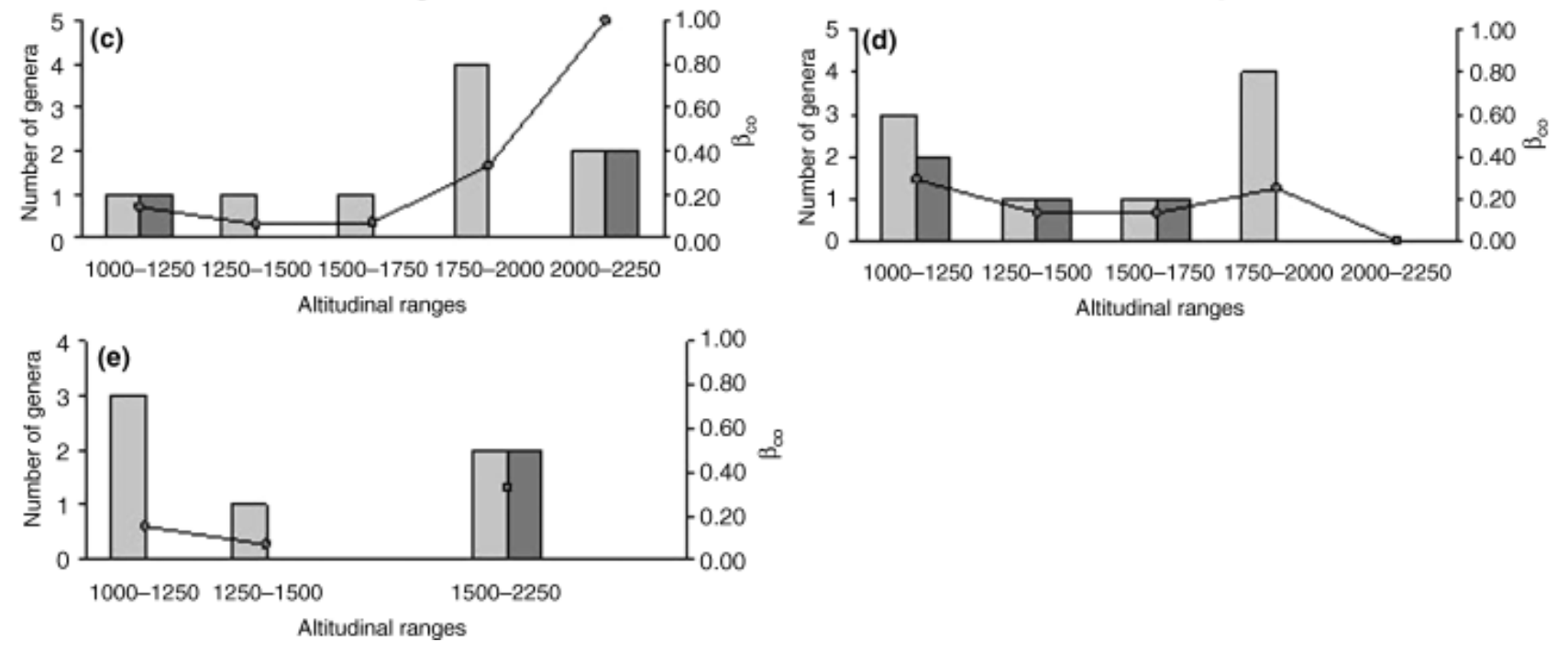
Figure 4 Changes in beta diversity $\left(\beta_{\mathrm{co}}\right)$ for genera along each elevational gradient (line). Beta diversity was calculated between two adjacent altitudinal levels. Grey bars, number of species lost; dark bars, number of species gained.
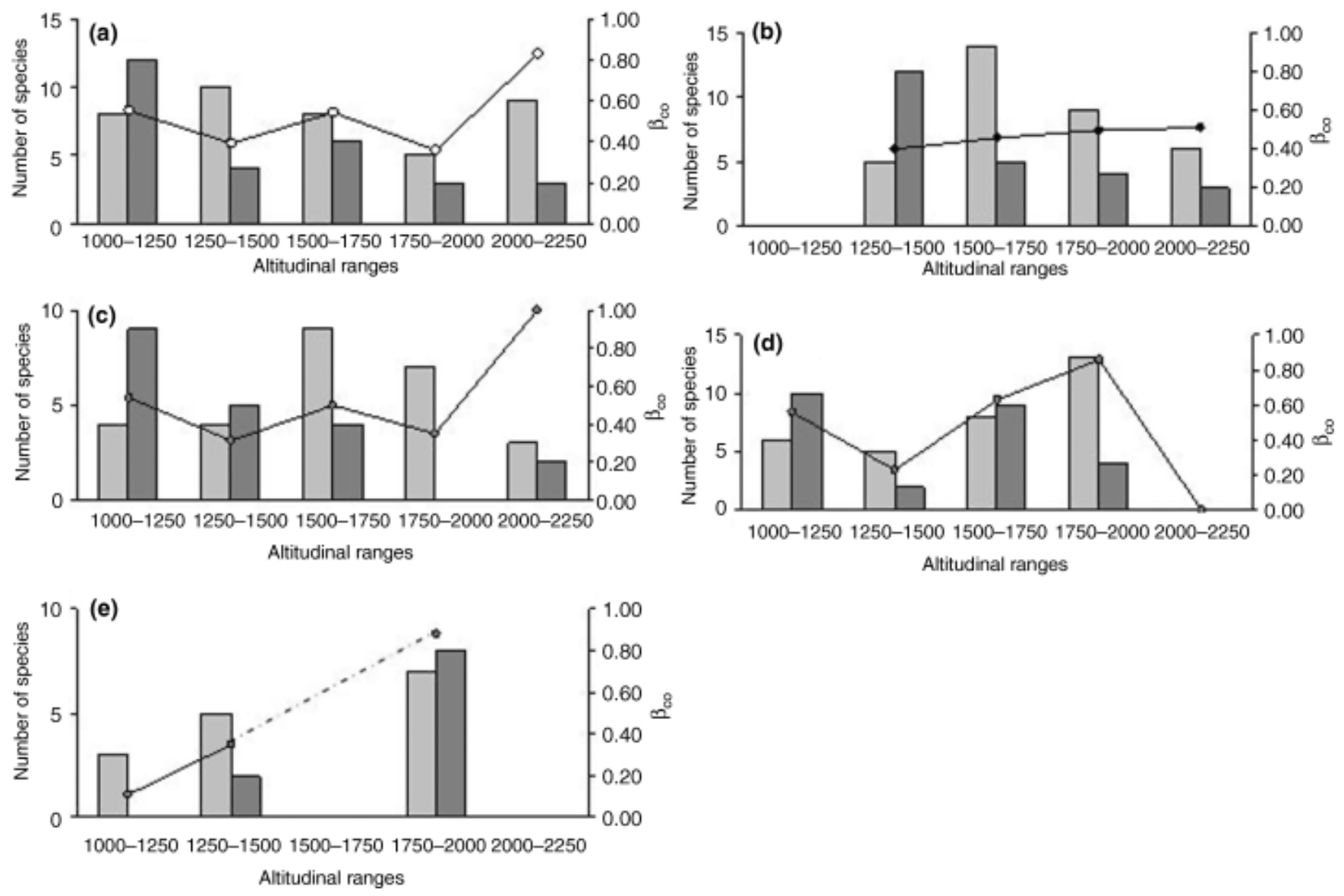
Figure 5 Cluster analysis of sites (27) using the Ward method as the linkage rule and Euclidean distance as the measure of similarity. A triangular $Q$-mode similarity matrix of sites was computed from the rectangular matrix of species abundance on each site using the percentage dissimilarity measure (PD; Ludwig \& Reynolds, 1988). Below, locations of the two main clusters of sites derived. Sites in the dendrogram are represented by the combination of letters (Fig. 1) and altitudes (m).
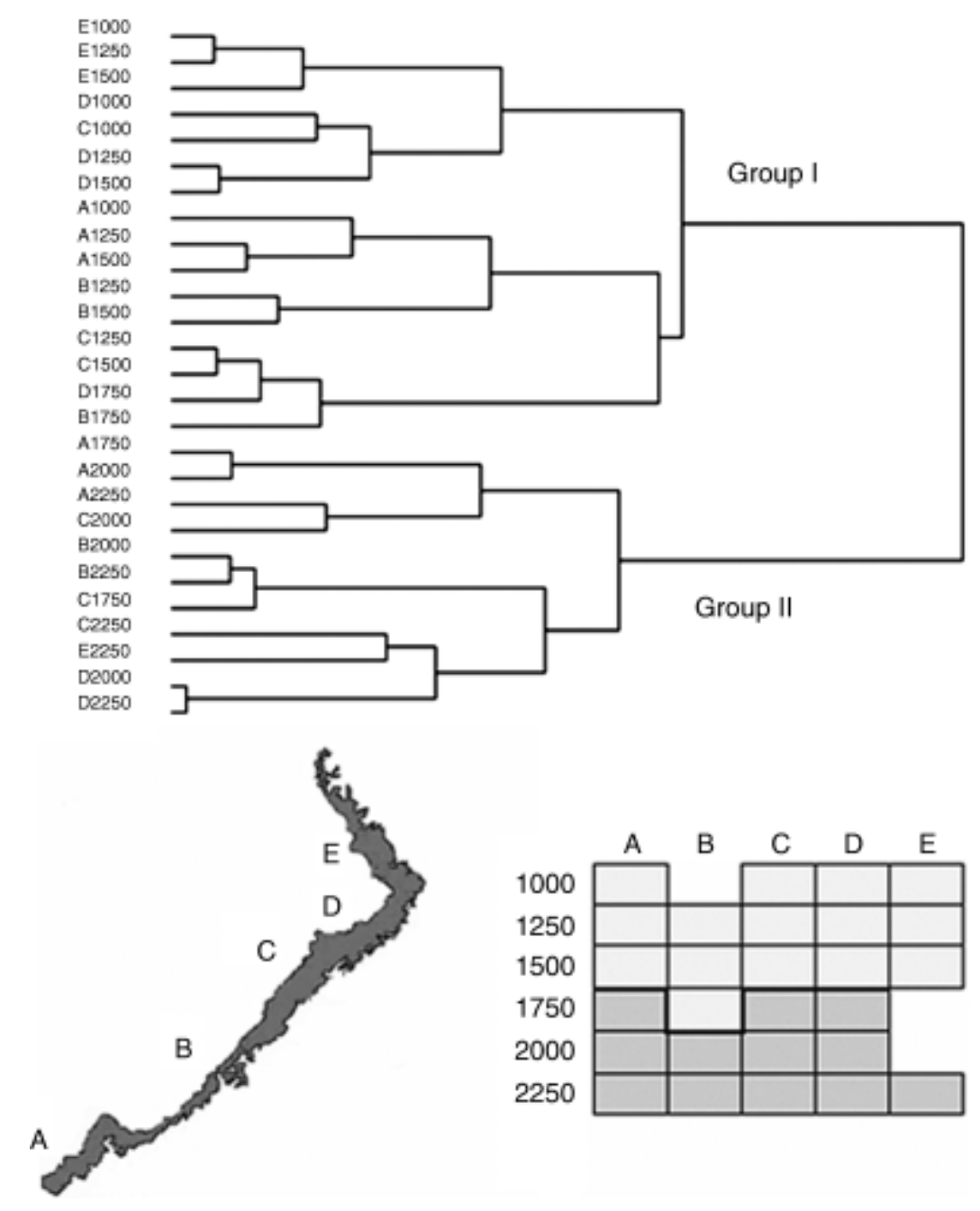
Figure 6 Spatial distribution for the genera Deltochilum and Uroxys along each elevational gradient. Letters represent the sites as in Figure 1. Note the apparent elevational segregation with some species exclusive to mid and high altitude mountains. Deltochilum $\left(\mathrm{D}_{\mathrm{m}}=D\right.$. mexicanum; $\mathrm{D}_{\mathrm{t}}=D$. teselatum; $\mathrm{D}_{\mathrm{h}}=$ D. hypponum; $\mathrm{D}_{1}=D$. sp. 1 ; $\mathrm{D}_{2}=D$. sp. $2 ; \mathrm{D}_{3}=D$. sp. $3 ; \mathrm{D}_{4}=$ D. sp. $4 ; \mathrm{D}_{5}=D$. sp. $5 ; \mathrm{D}_{6}=D$. sp. $6 ; \mathrm{D}_{7}=D$. sp. 7 ; $\mathrm{D}_{8}=D$. sp. $8 ; \mathrm{D}_{9}=D$. sp. 9). Uroxys $\left(\mathrm{U}_{1}=U\right.$. sp. 1; $\mathrm{U}_{2}=U$. sp. 2; $\mathrm{U}_{3}=U$. sp. 3; $\mathrm{U}_{4}=U$. sp. $4 ; \mathrm{U}_{5}=U$. sp. 5; $\mathrm{U}_{6}=U$. sp. $6 ; \mathrm{U}_{7}=U$. sp. 7; $\mathrm{U}_{8}=U$. sp. 8; $\mathrm{U}_{9}=U$. sp. 9; $\mathrm{U}_{10}=U$. sp. $10 ; \mathrm{U}_{11}=U$. sp. $11 ; \mathrm{U}_{12}=U$. sp. $12 ; \mathrm{U}_{13}=U$. sp. $13 ; \mathrm{U}_{14}=U$. sp. 14).

\begin{tabular}{|c|c|c|c|c|c|c|}
\hline & & Deltochilu & um & & & \\
\hline & 2250[ & $D_{h}, D_{1}$ & $D_{h}$ & & $D_{h}, D_{3}$ & $\mathrm{D}_{5}, \mathrm{D}_{9}$ \\
\hline & 2000 & $D_{t}, D_{2}$ & $D_{t}, D_{2}, D_{4}$ & $D_{h}, D_{2}$ & $\mathrm{D}_{\mathrm{h}}, \mathrm{D}_{3}$ & \\
\hline & 1750 & $D_{t}$ & $D_{t}, D_{m}, D_{5}$ & $D_{h}, D_{2}$ & $D_{m}$ & \\
\hline & 1500 & $D_{t}, D_{6}$ & $\mathrm{D}_{\mathrm{t}}, \mathrm{D}_{\mathrm{m}}, \mathrm{D}_{4}, \mathrm{D}_{6}$ & $\mathrm{D}_{\mathrm{m}}, \mathrm{D}_{5}$ & $\mathrm{D}_{5}$ & $\mathrm{D}_{5}$ \\
\hline D & 1250 & $D_{6}, D_{8}$ & $\mathrm{D}_{6}$ & $\mathrm{D}_{\mathrm{m}}, \mathrm{D}_{5}$ & $\mathrm{D}_{5}$ & $\mathrm{D}_{5}$ \\
\hline DI & 1000 & $\mathrm{D}_{6}, \mathrm{D}_{7}$ & & $\mathrm{D}_{5}$ & $D_{5}$ & $\mathrm{D}_{5}$ \\
\hline$E$ & & $A$ & $B$ & $\mathrm{C}$ & D & $E$ \\
\hline$\underline{\underline{z}}$ & & Uroxys & & & & \\
\hline D) & 2250 & $\mathrm{U}_{1}$ & & & & $\mathrm{U}_{6}, \mathrm{U}_{7}, \mathrm{U}_{10}$ \\
\hline $\bar{\nu}$ & 2000 & $\mathrm{U}_{1}, \mathrm{U}_{11}$ & $\mathrm{U}_{3}, \mathrm{U}_{9}$ & & & \\
\hline & 1750 & $\mathrm{U}_{1}, \mathrm{U}_{2}, \mathrm{U}_{11}$ & $\mathrm{U}_{9}$ & $\mathrm{U}_{6}, \mathrm{U}_{9}$ & $\mathrm{U}_{6}, \mathrm{U}_{9}, \mathrm{U}_{11}$ & \\
\hline & 1500 & $\mathrm{U}_{4}, \mathrm{U}_{11}$ & $\mathrm{U}_{5}, \mathrm{U}_{11}, \mathrm{U}_{12}$ & $\mathrm{U}_{9}$ & $\mathrm{U}_{13}$ & $U_{9}, U_{11}$ \\
\hline & 1250 & $\mathrm{U}_{4}, \mathrm{U}_{11}$ & $\mathrm{U}_{5}$ & $U_{9}, U_{11}, U_{12}$ & $\mathrm{U}_{13}, \mathrm{U}_{14}$ & $\mathrm{U}_{8}, \mathrm{U}_{11}$ \\
\hline & 1000 & $\mathrm{U}_{4}$ & & & $\mathrm{U}_{14}$ & $\mathrm{U}_{8}, \mathrm{U}_{11}$ \\
\hline & & A & B & C & D & $\mathrm{E}$ \\
\hline
\end{tabular}


Table 1 Slopes of variation in the cumulative number of dung beetle species and genera by altitude for the five mountain regions (see Fig. 1)

\begin{tabular}{|l|l|l|l|l|}
\hline \multicolumn{1}{|c|}{ Region } & \multicolumn{1}{|c|}{ Species } & \multicolumn{1}{|c|}{ Genus } & \multicolumn{1}{|c|}{$\boldsymbol{~ F}$} & \multicolumn{1}{|c|}{$\boldsymbol{P}$} \\
\hline A & $20.11^{* *}$ & $1.60^{* *}$ & $F_{(1,9)}=54.66$ & $<0.001$ \\
\hline B & $22.00^{* *}$ & $3.60^{*}$ & $F_{(1,7)}=36.56$ & $<0.001$ \\
\hline C & $14.97^{* *}$ & $1.71^{*}$ & $F_{(1,9)}=34.93$ & $<0.001$ \\
\hline D & $20.46^{* *}$ & $3.09^{*}$ & $F_{(1,9)}=32.61$ & $<0.001$ \\
\hline E & $8.57^{*}$ & $1.71 \mathrm{~ns}$ & $F_{(1,5)}=17.10$ & 0.009 \\
\hline
\end{tabular}

$F$, ANCOVA results indicate whether the effect of taxonomic category (species or genus) is statistically significant for these slope scores: ${ }^{*} P<0.05$; $* * P<0.01$; $* * * P<0.001$.

Table 2 Number of genera, species (mean $\pm \mathrm{SD}$ ) and number of shared species of dung beetle according to cluster analysis (group I, sites $<1500-1750$; group II, sites $>1750$ $2000 \mathrm{~m}$ a.s.1.)

\begin{tabular}{|l|l|l|l|l|l|l|}
\hline \multicolumn{2}{|c|}{} & \multicolumn{2}{|c|}{ Genera } & \multicolumn{2}{c|}{ Species } & \multicolumn{2}{c|}{ Shared } \\
\cline { 2 - 7 } Group & Number & $\begin{array}{c}\text { Mean } \\
\text { number per } \\
\text { site }\end{array}$ & Number & $\begin{array}{c}\text { Mean } \\
\text { number per } \\
\text { site }\end{array}$ & $\begin{array}{c}\text { Genera } \\
\text { (number) }\end{array}$ & $\begin{array}{c}\text { Species } \\
\text { (number) }\end{array}$ \\
\hline I & 19 & $8.5 \pm 1.6$ & 81 & $14.5 \pm 3.8$ & & \\
\hline & & & & & 8 & 20 \\
\hline II & 11 & $4.7 \pm 1.8$ & 40 & $7 \pm 3.4$ & & \\
\hline
\end{tabular}

